\title{
Maskot Kota Yogyakarta
}

\author{
Paku Kusuma $^{1}$, Dharsono ${ }^{2}$, \\ Dwi Marianto ${ }^{3}$, Guntur ${ }^{4}$ \\ ${ }^{1}$ Prodi DKV, Fak. Industri Kreatif, Universitas Telkom \\ ${ }^{2}$ ISI Surakarta \\ ${ }^{3}$ ISI Yogyakarta \\ ${ }^{4}$ ISI Surakarta \\ masterpaku@telkomuniversity.ac.id
}

\begin{abstract}
Maskot tidak sekedar bentuk yang tanpa makna, didalamnya terdapat nilai filosofis yang membawa pesan penting dari suatu cita-cita bersama. Sistem identitas menjadi penghubung antara kajian keberadaan maskot dan kebutuhan pencitraan suatu daerah. Setiap daerah, tentu saja memiliki keunikan yang membedakan dengan daerah lainnya; keunikan tersebut akan memberikan keuntungan tersendiri bagi entitas yang ada dalam ruang lingkupnya. Begitu pula untuk Daerah Istimewa Yogyakarta, yang meskipun notabene telah menyandang predikat daerah istimewa akan tetapi perlu juga dipikirkan membangun identitas wilayahnya sebagai asosiasi penguatnya. Fokus dalam penelitian kualitatif ini akan menguak sejauh mana peran Pemerintah Daerah Istimewa Yogyakarta dalam proses pemikiran membuat "maskot" yang menunjukan keistimewaannya. Kajian penulisan dengan penekanan pandangan kebudayaan melalui UU keistimewaan D.I. Yogyakarta yang disandingkan dengan pemikiran mengenai pencitraan kota.
\end{abstract}

Kata Kunci: maskot kota, identitas wilayah, keistimewaan Yogyakarta.

\section{Yogyakarta City Mascot}

Mascot is not just a meaningless form, there's a philosophical value followed its form, coming with an important message from a shared goal. The identity system becomes the link between the study of the mascot's existence and the imaging of a city. Each region, always has their uniqueness that distinguishes it self from other regions. This uniqueness will provide its own advantages for the whole entities that are living within its scope of area. This case also the same for the Special Region of Yogyakarta, which although in fact has carried the title of a special region but needs to be considered building its regional identity to be more special as an association of its reinforcement. The main aim from this qualitative research, will reveal the extent to which the Government of the Special Region of Yogyakarta in the thought process of making a "mascot" that shows its features. Writing studies with emphasis on cultural views through the D.I privilege law. Yogyakarta is juxtaposed with thoughts on their city imaging.

Keywords : Mascot of a city, regional identity, specialties region of Yogyakarta.

Proses Review : 1 - 20 Mei 2020, Dinyatakan Lolos: 29 Mei 2020 


\section{PENDAHULUAN}

Daerah Istimewa Yogyakarta memiliki ikatan historis yang tidak bisa dilepaskan dengan keberadaan Negara Republik Indonesia. Pada masa perang revolusi yakni tahun 19451949, masyarakat Yogyakarta bersama-sama segenap entitas republik melakukan perlawanan untuk meraih kemerdekaan dari penjajahan Belanda. Kala itu Yogyakarta bahkan sempat menjadi ibukota negara Indonesia; Sultan Hamengku Buwono IX juga banyak menghibahkan bantuan finansial bagi negara yang baru berdiri ini. Lebih lanjut sikap Raja Kraton Ngayojokarto menyatakan bergabung dengan negara baru bernama Indonesia yang tertuang dalam maklumat 5 September 1945.

Maklumat ini menyatakan bahwa Kraton Ngayojokarto Hadiningrat dan Kadipaten Pakualaman bergabung dengan negara baru bernama Indonesia; situasi yang memberikan gambaran betapa Yogyakarta merupakan daerah yang sangat lekat dengan nilai-nilai kejuangan. Perihal kebudayaan, keberadaan Kraton Ngayojokarto menjadi pusat dari segala budaya dan tradisi yang hingga kini masih terjaga dengan baik. Predikat istimewa memang layak disandang oleh Yogyakarta jika menilik latar belakang semuanya itu.

Disahkannya UU Nomor 13 Tahun 2012 tentang status Keistimewaan Daerah Istimewa Yogyakarta, memberikan harapan bagi rakyat, khususnya rakyat propinsi DIY yang antusias akan terwujudnya kesejahteraan. Disahkannya UU Keistimewaan tersebut, maka secara konstitusional DIY diberikan otoritas untuk mengatur tata kelola pemerintahannya secara mandiri sebagaimana yang tertuang pada pasal-pasal dalam Undang-Undang Keistimewaan DIY. Sementara pada sisi demokrasi, UU tentang Keistimewaan DIY jadi tantangan tersendiri dalam pengembangan dinamika demokrasi substantive. Diberikannya kewenangan kepada daerah untuk menyusun tata kelola pemerintahan dengan bersumber pada nilai-nilai budaya lokal memungkinkan terjadinya keselarasan dinamika masyarakat yang bisa meminimalkan terjadinya resistensi.

Keistimewaan Daerah Istimewa Yogyakarta, yang diatur dalam Undang-Undang Nomor 13 Tahun 2012, memberikan kewenangan penuh kepada Daerah Istimewa Yogyakarta dalam hal tata kelola pemerintahan. Keistimewaan tersebut adalah diberikannya otoritas untuk mengatur lima urusan yang meliputi: cara pengisian jabatan gubernur dan wakil gubernur, tentang urusan kelembagaan, urusan kebudayaan, mengenai pertanahan, dan urusan Tata $\mathrm{Ru}-$ ang. Keberadaan UU Keistimewaan DIY, sangat strategis untuk mengimplementasikan kebijakan-kebijakan yang membawa kebajikan bagi warga masyarakat Yogyakarta. Otoritas yang berlandaskan kontitusi akan memberikan dampak kepada pengambil keputusan untuk membuat kebijakan yang istimewa. Konteks yang sederhana memaknai kebijakan istimewa adalah kebijakan yang akan mem- bawa masyarakat dalam kondisi sejahtera. Kebijakan yang baik selalu memberikan ruang bagi masyarakat untuk terlibat. Keterlibatan masyarakat sangatlah diperlukan, partisipasi masyarakat dalam membuat kebijakan akan meminimalkan konflik yang disebabkan oleh kebijakan tersebut. Karena itu, birokrasi dalam hal ini adalah pembuat kebijakan, hidup dan bekerja dengan mengikuti perkembangan di masyarakat dan mengacu pada jamannya.

Menurut Hummel, "bureaucracy replaces society", sebuah pernyataan yang menunjukan bahwa birokrasi mengambil peran yang harus dimainkan oleh masyarakat. Birokrasi dipahami sebagai institusi yang seakan mengancam eksisitensi masyarakat, tetapi disisi lain, birokrasi dipahami sebagai sebuah institusi yang bertanggung jawab atas apa yang diinginkan masyarakatnya. Dalam pengertian yang terakhir, birokrasi akan bekerja sesuai dengan perkembangan apa yang terjadi dalam masyarakat (Pramusinto, 2009).

Undang-Undang Keistimewaan, diharapkan memunculkan masyarakat ideal yang istimewa, dengan tingkat pendidikan dan pengetahuan berlandaskan nilai-nilai budaya dan tradisi yang berakar dari asali. Menghormati perbedaan dan selalu menjaga harmoni dalam kehidupan sosial kemasyarakatan. Mengembangkan kreatifitas dengan memaksimalkan ide dan gagasan yang berwawasan global tanpa meninggalkan sisi lokalitasnya.

Oleh karena itu Daerah Istimewa Yogyakarta yang istimewa dimaknai sebagai masyarakat yang makmur secara ekonomi sehingga perlu terus dikembangkan pembangunan bidang perekonomian baik yang menyangkut industri, perdagangan, pertanian, dan sektor jasa lainnya yang ditopang dengan pembangunan sarana prasarana ekonomi. Masyarakat istimewa adalah masyarakat yang tingkat pengetahuan dan kearifan tinggi, ditandai dengan tingkat pendidikan dan tingkat partisipasi pendidikan penduduknya tinggi, serta jumlah dan kualitas tenaga ahli dan tenaga profesional yang dihasilkan oleh sistem pendidikan memadai.

Otoritas yang diberikan pemerintah pusat, dengan diberikannya status keistimewaan pada Daerah Istimewa Yogyakarta mengandung tanggung jawab yang besar bagi seluruh stakeholder, untuk bersama-sama mewujudkan sisi keistimewaan tersebut. Implementasi undang-undang keistimewaan menjadi penting sebagai perwujudan menuju masyarakat yang sejahtera. Kontek yang mendasar, representasi sejahtera terwujud dengan tercukupinya kebutuhan masyarakat yang paling dasar, yaitu: pendidikan, kesehatan dan perumahan.

Implementasi undang-undang keistimewaan yang terwujud dengan berbagai kebijakan pada akhirnya memberikan harapan yang diidealkan bersama, yaitu terwujudnya masyarakat yang istimewa. Kolaborasi antara: kraton Yo- 
gyakarta sebagai pusat kebudayaan, kampus sebagai representasi akademik yang menyumbangkan segala bentuk pemikiran, pemerintah yang berfungsi sebagai regulator dan fasilitator, sektor industri dan media sebagai partner kerja, serta kampung sebagai perwujudan masyarakat sebagai penerima manfaat dan memberikan partisipasi aktif dalam berbagai hal. Konsep kolaborasi yang dikenal dengan sistem helix ini akan semakin meneguhkan keistimewaan DIY.

Imbas secara langsung dari keterlibatan elemen-elemen helix ini memunculkan adanya penggalian aset yang dimiliki oleh daerah secara signifikan guna memberikan masukan agar pengelolaan daerah dan pembangunan berjalan dengan baik. Pencitraan daerah tak pelak juga menjadi salah satu yang menjadi aset pemikiran. Perkembangan ini memunculkan adanya kepentingan mengidentifikasi tiap daerah yang terangkum dalam banyak program, mulai dari slogan daerah, bahasa, kesenian, budaya sampai rupa wujud tata wilayah untuk memberikan citra positip terhadap wilayahnya.

Citra disini merupakan gambaran tentang suatu hal yang merupakan akumulasi dari pengetahuan, pengalaman dan keterpaparan terhadap obyek. Pencitraan wiayah menjadi penting karena sebagai pusat pertumbuhan ekonomi dan politik (Yananda dkk., 2014).

Pencitraan dimulai dengan membangun identitasnya, sebab sebuah wilayah terdiri dari berbagai entitas dan pemangku kepentingan yang memiliki tujuan dan kepentingan yang berbeda-beda. Identitas adalah sebuah cerminan diri, dalam hal ini setiap daerah pada dasarnya telah memiliki identitas yang tersimpan dalam memori kolektif kelompok yang menjadi pemangku kepentingannya. Identitas kota juga tersimpan dalam artefak fisik yang menjadi penanda kota, termasuk di dalamnya dokumen-dokumen masa lalu, kini atau masa depan yang membantu pemahaman untuk menemukenali identitas yang dimiliki sebuah daerah.

Identitas memungkinkan sebuah tempat menjadi berbeda dari tempat lain atau daerah yang menjadi pesaingnya. Disinilah industri kreatif memegang peranannya dengan memadukan berbagai unsur memorabilia kolektif kota ini ke dalam bentuk visual, yang bisa menambah asosiasi baru yang lebih kuat dari asosiasi terdahulu. Bentuk visual ini bisa menjadi alternatif solusi bagi pemangku kepentingan dalam menentukan asosiasi baru guna pencitraan kota, sebab bentuk visual seringkali lebih mudah tertanam dalam benak dan mengikat kuat perasaan untuk memiliki (sense of belonging).

Penanaman asosiasi yang kuat ini idenya bersumber dari paduan olahan kekayaan sejarah, budaya atau hasil dari sumber dayanya.
D.I. Yogyakarta saat ini telah memiliki asosiasi seperti lambang kraton, juga berupa lambang pemerintahan dan tagline "Yogyakarta berhati nyaman". Asosiasi visual lain perlu dipikirkan guna memperkuat citranya, seperti maskot wilayah. Adapun maskot adalah bentuk visual yang keberadaannya tidak terpisahkan dengan logo ataupun lambang. Penggunaan maskot akan memberikan kesempatan terjadi komunikasi dua arah yang lebih personal antara pemangku kepentingan dan pihak luar. Maskot menjadi penting sebagai pembeda dengan wilayah lainnya, juga penanda yang unik.

Maskot adalah suatu bentuk personifikasi visual yang dibuat melalui proses olah berpikir desain sebagai sosok penyemarak, identifikasi, pencitraan dan sebagai perlambang dari sisi keberuntungan (Kusuma, 2012). Sebagai hasil dari pengolahan berpikir maka bentuk visual maskot merupakan ragam kekayaan intelektual. Maskot hadir sebagai bagian dari komunikasi visual yang menunjukan ciri yang diisyaratkan sebagai representasi ideal dari berbagai hal yang terjadi di suatu daerah. Citra visual yang ada dalam maskot untuk wilayah, merupakan representasi atas identitas suatu daerah.

Peran maskot menjadi penting, kehadirannya sebagai alat komunikasi yang membawa misi tertentu, sekaligus sebagai media promosi yang sangat strategis. Menurut Wheeler (2009) salah satu elemen (pictorial mark) dari brand identity adalah maskot. Maskot bagi wilayah merupakan representasi yang olah penciptaannya merunut benang merah dari berbagai hal yang ada di suatu daerah. Hal penunjang yang tak kalah penting dari peranan maskot, yaitu sebagai kebanggaan (pride) yang paling diyakini sebagai faktor kesuksesan dari suatu kampanye.

Karakter yang akan muncul menampakan identitas secara sangat ikonik. Atas citra yang ikonik tersebut maskot sangatlah strategis sebagai unsur terakhir dalam sebuah proses kampanye. Paul Butler, Kevin Green dan Dale Gavin dalam buku The principles of pride (2013), menuliskan: perhaps the most well-known and visible aspect of the Pride campaign: the mascot. Maskot mungkin terlihat ceria dan tampak biasa saja tapi dibalik tampilannya adalah beragam simbol yang kompleks, sehingga ini adalah keilmuan yang sangat serius.

Penelitian ini bertujuan untuk melihat implementasi UU Keistimewaan bagi jalannya kebijakan pencitraan di kota Yogyakarta dalam memberikan dampak yang pada akhirnya mampu memberikan kesejahteraan bagi rakyat Yogyakarta. Perihal status keistimewaan yang tentunya berkaitan erat dengan rasa bangga serta identitas yang akhirnya melatarbelakangi tampilan visual kota. Hal yang berhubungan dengan sektor ekonomi kreatif, yaitu mengenai guliran ide maskot kota Yogyakarta. 


\section{METODOLOGI PENELITIAN}

Maskot dibuat sebagai tanda, identitas yang diciptakan untuk menunjukan keberadaan yang penciptaannya bersinggungan berbagai sisi: budaya, lingkungan serta kejadian-kejadian yang memiliki nilai hitoris. Menurut Saussure, tanda selalu memiliki tiga wajah: tanda itu sendiri (sign), aspek material (bisa berupa suara, huruf, bentuk, gambar, gerak), dari tanda yang berfungsi menandakan atau yang dihasilkan dari aspek material (signifier) dan aspek mental atau konseptual yang ditunjuk oleh aspek material (signified) (Sunardi, 2002).

Kehadiran maskot erat hubungannya dengan penciptaan yang diupayakan oleh kreator yang merancang berdasarkan ide dan gagasan. Ide dan gagasan yang ada, memberikan rangsangan para kreator untuk mewujudkannya dengan citra visual, dalam kontek ini kreator berupaya memvisualisasikan bentuk yang ideal. Gagasan bentuk ideal yang dimaksudkan harus mampu merangkum semua tujuan dalam kemasan unik tampilan dengan dasar prinsip perancangan.

Perancangan berkaitan erat dengan keilmuan desain; salah satu jurusan dalam desain yang intens membahas bentuk-bentuk visual terkait komunikasi dan promosi adalah Desain Komunikasi Visual (DKV). Desain Komunikasi Visual adalah disiplin ilmu yang bertujuan mempelajari konsep komunikasi dan ungkapan kreatif melalui media untuk menyampaikan pesan dan gagasan secara visual dengan olahan elemen grafis. Sehingga gagasan dapat diterima oleh orang lain yang menjadi sasaran penerima pesan (Kusrianto, 2007).

Landasan dalam perancangan maskot untuk kota adalah karakteristik masyarakat beserta entitas yang terlibat dalam ruang lingkup wilayah tersebut. Menurut Koentjoroningrat pengertian kebudayaan adalah "keseluruhan sistem gagasan, tindakan, dan hasil karya manusia dalam rangka kehidupan masyarakat yang dijadikan milik diri manusia dengan belajar". Proses penciptaan maskot, merupakan gagasan yang diwujudkan dengan sebentuk benda yang telah dikaji dengan berbagai riset dan pertimbangan.

Pengertian maskot ( $n$ ) adalah orang, binatang, atau benda yang diperlakukan oleh suatu kelompok sebagai lambang pembawa keberuntungan atau keselamatan (KBBI). Adi Kusrianto (2007) menuliskan bahwa maskot adalah tokoh representatif, produk simbolistik dan alat untuk berkomunikasi yang digunakan sebagai alat dalam mencitrakan dan sosialisasi seseorang/ identitas kota/ produk/ organisasi/ event tertentu. Maskot melambangkan nilai-nilai yang terkandung di dalamnya yang mencitrakan karakter produk sebagai pendukung mengangkat identitas produk dan memiliki peran dalam pemasaran, juga sebagai alat komunikasi efektif dan membantu menarik perhatian user dan lebih dikenali.
Sebagai produk simbolik tentu saja bentuk ini harus bisa dimunculkan dalam berbagai jenis macam kegiatan dan luwes ditampilkan di ragam media seperti halnya sebuah logo atau lambang. Maskot sebagai suatu petanda yang dibuat berdasarkan konvensi harus mampu mengadaptasi keinginan dari target pasarnya yang diolah sedemikian rupa agar memiliki kedekatan secara personal dan utuh dalam kesatuan pandangan. Keberadaan maskot menjadi tidak terpisahkan sebagai kesatuan unit dalam sistem identitas, bahkan lebih lanjut bisa dijadikan jembatan untuk kebutuhan komunikasi dengan target sasaran yang diinginkan. (Kusuma, 2018).

\section{ANALISIS}

Kota Yogyakarta kerapkali memunculkan tampilan visual dalam berbagai ajang kegiatan, baik skala lokal, nasional maupun internasional. Hal tersebut sudah berlangsung dalam rentang waktu yang cukup lama, tetapi meskipun ada banyak wujud visual yang telah ditampilkan ternyata belum ada satupun sosok yang ditetapkan sebagai maskot daerah. Hingga menjelang perayaan sewindu keistimewaan DIY baru bergulir ide mengenai maskot untuk kota Yogyakarta. Perbincangan di museum keistimewaan dalam tajuk penyambutan sewindu keistimewaan Yogyakarta yang sedianya akan dilangsungkan awal bulan September nanti menjadi salah satu awalan dalam pemikiran pembentukan maskot kota Yogyakarta.

Penciptaan maskot sebagai identitas daerah, menjadi penting keberadaannya. Pada satu sisi sebagai duta, maskot mengandung pesan untuk merepresentasikan identitas suatu daerah, yang keberadaannya dikaji dengan benar sehingga memberikan pemahaman kepada khalayak akan identitas daerahnya. Pada sisi yang lain, maskot yang tercipta diharapkan mampu memberikan dampak psikologis kepada warga masyarakat yang bertujuan menimbulkan rasa kecintaannya pada daerah.

Sebagai daerah yang memiliki potensi besar pada sektor jasa, perkembangan industri kreatif menjadi penting untuk memberikan kontribusinya. Penciptaan maskot daerah memiliki peran strategis untuk mendukung keberadaan Yogyakarta sebagai kota tujuan wisata. Dalam khasanah budaya popular, ciri khas produk yang dihasilkan setidaknya mempunyai sifat yang menarik dan mudah diakses. Ketika diproduksi harganya kompetitif, menarik perhatian segala usia dan tanpa batasan gender (Haryanto, 2015).

Literatur mengenai ekonomi kreatif di dunia memperlihatkan adanya dua pendapat utama mengenai pendefinisian ekonomi kreatif, yang pertama menggunakan terminologi industri seni (art industry/creative art industry) dan yang kedua menggunakan terminologi industi budaya (culture industry). Dalam sektor industri kreatif, "maskot' yang telah berhasil menjadi bagian penting bagi kehidupan masyarakatnya dengan pendekatan budaya, akan memberikan 
peluang bagi pelaku industri kreatif untuk membuat produk-produk turunan yang berdasarkan pada keberadaan "maskot" tersebut. Valuasi keekonomian produk dengan berbagai turunannya, akan mengerakan sektor lapangan pekerjaan dan memberikan nilai tambah bagi pendapatan asli daerah.

Ekonomi kreatif akan menjadi penting bagi perkembangan perekonomian pada masa yang akan datang. Kreatifitas yang bersumber kepada daya kepekaan instingtif merupakan sisi yang tidak mengenal batasan usia. Keberadaan kreator yang bisa lahir baik dari lembaga pendidikan ataupun non pendidikan sangat memungkinkan untuk berkompetisi dalam menciptakan produk-produk kreatif yang bernilai keekonomian. Kreatif menjadi energi yang terbarukan, hadir dari ide dan gagasan yang ideal selalu berpijak pada sisi historical dan nilai-nilai kearifan lokal yang selalu memberikan benang merah pada masa lalu dan masa depan.

Proses kreatif tentu saja memerlukan landasan berpikir karena pijakan keilmuan adalah esensi dari kekuatan kreativitas. Pembahasan mengenai maskot tentu saja memerlukan energi kreatif tersendiri yang dimampatkan dari beberapa rumusan deskripsi. Kota Yogyakarta tentunya sebagai daerah istimewa memiliki rumusan pemikiran yang perlu dijadikan bahan pertimbangan dalam proses penciptaan, antara lain:

\section{Kebijakan dan Industri Kreatif}

Daerah Istimewa Yogyakarta memiliki berbagai predikat: kota pendidikan, kota budaya dan sebagai kota tujuan wisata baik domestik dan mancanegara. Predikat-predikat tersebut menunjukan bahwa D.I. Yogyakarta menjadi magnet yang memiliki daya pikat serta keunikan. Potensi besar yang ada, kelihatannya belum dimaksimalkan. Indikator tersebut bisa dilihat dari kebijakan-kebijakan yang ada masih bersifat inkremental. Ciri kebijakan tersebut lebih pada sifat kehati-hatian para pengambil kebijakan, belum menawarkan suatu hal yang bersifat kebaruan.

Menurut Yehezkel Dror, model inkremental dalam membuat keputusan cenderung menghasilkan kelambanan dan berpihak pada status quo, konsekuensinya adalah tidak terjadinya perubahan yang signifikan. UU Keistimewaan, memberikan kewenangan penuh kepada pembuat kebijakan untuk melahirkan kebijakan yang inovatif. Berbagai perguruan tinggi yang ada merupakan mitra strategis bagi pemerintah daerah untuk bersama-sama melahirkan kebijakan yang berwawasan kedepan.

Pada kontek kebijakan, kemajuan di industri kreatif belum menciptakan regulasi yang baik dalam memberikan ruang bagi para kreator. Penciptaan maskot daerah yang secara karya berada pada wilayah kreator, namun belum ditangkap oleh pengambil kebijakan. Sejatinya hal tersebut sangatlah mungkin, pengambil kebijakan hanya tidak meng- etahui pentingnya maskot yang mempunyai nilai filosofis dan potensial secara keekonomian. Kebijakan publik yang inovatif itu sesungguhnya tidak hanya menekankan pada penggunaan ide-ide baru dan ilmu pengetahuan semata, tetapi justru kembali pada esensi dasar sebuah kebijakan, yaitu kemampuannya untuk menyelesaikan masalah sosial dan ekonomi. Kebijakan yang inovatif tersebut memerlukan beberapa prakondisi, seperti sumber daya manusia yang berkualitas, lingkungan kerja yang dinamis, integrasi dengan ilmu pengetahuan baru, serta kolaborasi masyarakat dan para pemangku kepentingan (stakeholder) lainnya (Purwanto,2019).

Kebijakan inovatif sangatlah diperlukan, sebagai daerah yang istimewa penciptaan maskot daerah menjadi penting, tidak saja secara filosis namun potensial memberikan nilai tambah secara ekonomis. Ketiadaan regulasi penciptaan maskot tersebut bisa dilihat, bahwa untuk D.I. Yogyakarta sampai saat ini belum muncul maskot daerah sebagai ikon yang menunjukan ciri khas identitas daerah. Kelambanan pengambil kebijakan sangatlah disayangkan. Birokrasi publik kita kehilangan ruang untuk berinovasi dan mengembangkan kreativitas juga karena kultur yang terbentuk dalam birokrasi adalah kultur yang menjunjung tinggi nilai-nilai yang menghargai keajegan, rutinitas, dan kepastian (Dwiyanto, 2016).

\section{Ide dan Gagasan}

Proses penciptaan maskot hadir bukan tanpa ruang, perancangannya sarat dengan nilai historis, karakter dan cara pandang. Jadi keberadaannya bukan ahistoris, "maskot" hadir sebagai bagian benang merah dari masa lalu, dari dinamika kolektif kerumunan yang memiliki cita-cita bersama, sebagai perekat emosional dan sangat mungkin pembawa kenangan. Kenangan yang sarat nilai akan jadi wacana yang membekas bagi pemirsanya. Hal yang akan memberikan kebanggaan bagi segenap entitas yang terlibat dalam ruang lingkup wilayahnya.

\section{Yogyakarta Kota Perjuangan}

Maklumat pengakuan tgl 5 September 1945, hingga menjadi ibukota negara pada 4 Januari 1946, menunjukan betapa Yogyakarta layak disebut sebagai kota perjuangan. Yogyakarta menjadi bagi keberadaan Negara Kesatuan Republik Indonesia. Tercatat dalam sejarah, bahwa Yogyakarta mengalami perjalanan revolusi fisik yang pernah terjadi di Indonesia. Berbagai pertempuran sengit pernah terjadi dibeberapa wilayah yang ada di Yogyakarta. Berujung pada Serangan Umum 1 Maret, merupakan peristiwa pertempuran fisik segenap entitas melawan penjajahan yang akhirnya membuka mata dunia internasional pada keberadaan Indonesia.

\section{Yogyakarta Kota Wisata}

Yogyakarta diuntungkan dengan landskap alamnya yang beragam tersebar di beberapa kabupaten. Keberadaan gunung berapi disisi utara memberikan kesuburan bagi 
alamnya, sementara dibagian selatan terdapat pantai yang memiliki mitologi dan sangat disakralkan oleh sebagaian penduduknya. Berbagai candi peninggalan masa lalu memberikan nuansa magis dengan berbagai narasi yang didalamnya terkandung pengetahuan yang sarat dengan nilainilai filosofis. Beragam kulinari yang hadir dan memiliki cita rasa beragam merupakan surga bagi para pemburu kuliner. Layanan transportasi dengan moda transportasi tradisional kereta kuda adalah ciri lain yang menjadi bagian penting bagi keberadaan Yogyakarta sebagai kota wisata.

\section{Yogyakarta Kota Pelajar}

Di Daerah Istimewa Yogyakarta terdapat berbagai perguruan tinggi negeri dan swasta dengan kualitas yang terbaik, sehingga juga menyandang predikat kota pelajar. Pemerintah daerah telah memberikan berbagai kebijakan dan fasilitas yang diharapkan dapat mendukung kelancaran studi bagi siapa saja yang sedang menuntut ilmu di Yogyakarta. Fasilitasi tersebut dinataranya adalah kehadiran bus (trans Yogya) yang menghubungkan antar berbagai kampus yang ada, sehingga mobilitas mahasiswa untuk menuju ke kampus semakin mudah dan cepat.

Keberadaan berbagai perpustakaan baik yang dikelola oleh pemerintah dan masyarakat dengan jam buka sampai malam, memberikan kesan bahwa Yogyakarta merupakan kota pelajar yang tidak hanya berhenti pada jargon.

\section{Yogyakarta Kota Budaya}

Kraton Ngayojokarto Hadiningrat yang masih aktif hingga saat ini dan menjadi satu-satunya kraton dengan pengakuan penuh di Indonesia, menjalankan laku tradisi dan budaya yang telah berlangsung ratusan tahun. Kraton sebagai pusat budaya memberikan pengaruh yang luar biasa terhadap tata nilai yang ada dimasyarakat Daerah Istimewa Yogyakarta. Kraton menjadi ikon budaya dan sumber berbagai pengetahuan. Representasi tersebut terdapat dalam berbagai serat, tari dan juga segala hal yang hingga saat ini masih terjaga dalam lingkungan Kraton Ngayojokarto Hadiningrat.

\section{SIMPULAN}

Daerah Istimewa Yogyakarta, merupakan daerah yang mendapatkan otoritas untuk mengatur berbagai hal sebagaimana diatur dalam UU Keistimewaan No 13 Tahun 2012. Diantaranya adalah mengatur tentang kebudayaan. Budaya pada intinya adalah system of signification, kalau tujuan kajian semiotika adalah mencari berfungsinya sistem tersebut, hal itu dilakukan karena disanalah dinamika budaya dapat diamati. Dalam sistem tersebut kita melihat kemungkinan anggota-anggota masyarakat untuk memilih, menggabungkan, dan mengungkapkan tanda-tanda yang tersedia (Sunardi. 2002). Pada bagian lain, merujuk pendapat dari Koentjoroningrat: kebudayaan adalah "keseluruhan sistem gagasan, tindakan, dan hasil karya manusia dalam rangka kehidupan masyarakat yang dijadikan milik diri manusia dengan belajar”.

Pemerintah kota Yogyakarta sebagai wilayah yang memiliki keistimewaan hendaknya perlu juga untuk memikirkan mengenai pencitraan kota yang selaras dengan kebudayaannya. Keberadaan UU Keistimewaan yang didalamnya mengatur tentang kebudayaan, sudah barang tentu akan memberikan keleluasaan bagi pemangku kebijakan kota Yogyakarta untuk melahirkan kebijakan yang inovatif. Salah satu jalan yang patut dilakukan adalah dengan memberikan penanda visual yang memiliki keunikan agar bisa menjadi tetenger bagi warga kota dan pendatang. Meski telah beberapa kali menciptakan figur visual dalam beberapa kegiatan acara tapi sejauh ini masih belum menciptakan visual maskot kotanya. Proses penciptaan "maskot" bisa diawali dari ide dan gagasan dengan jajak pendapat dari warga kota untuk selanjutnya dilakukan penelitian figur bekerjasama dalam sistem helix, sehingga menghasilkan kesimpulan berupa karya visual yang pada akhirnya menjadi milik bersama.

Daerah Istimewa Yogyakarta dengan berbagai predikat: kota perjuangan, kota wisata, kota pendidikan dan kota budaya; merupakan sumber ide dan gagasan untuk menciptakan maskot sebagai identitas daerah. Menilik dari aspek regulasi, keberadaan maskot mestinya diampu oleh kedinasan yang terkait. Pentingnya kedinasan yang bertanggug jawab atas penciptaan "maskot" memberikan legalitas atas regulasi yang berkenaan dengan penciptaan tersebut. Sehingga alur kebijakan tentang penciptaan "maskot" melewati proses yang sebagaimana mestinya.

Dengan demikian penciptaan maskot daerah menjadi "agenda setting". Untuk selanjutnya masuk pada "formulasi kebijakan" yang didalam membahas tentang mekanisme penciptaan maskot yang diikuti oleh para pakar yang berkompeten. Setelah terbentuknya mekanisme dan berbagai hal tentang penciptaan maskot, masuklah kepada "legalitas kebijakan", proses ini lebih kepada sosialisasi dan menerima berbagai masukan dari masyarakat yang bertujuan untuk meyakinkan masyarakat bahwa penciptaan maskot adalah suatu hal yang sangat penting dan memberikan nilai tambah kepada pemerintah dan juga masyarakat. Pada akhirnya setelah melewati berbagai proses, implementasi penciptaan maskot diumumkan kepada khalayak, hal ini menjadi penting karena maskot yang muncul melibatkan pakar yang berkompeten dan partisipasi masyarakat.

Maskot daerah penting kehadirannya ditinjau dari sisi manapun. Maskot lahir tidak begitu saja, dia ada sebagai bagian dari benang merah sejarah peradaban suatu daerah. Daerah Istimewa Yogyakarta, sebagai daerah yang mempunyai jejak panjang peradaban telah tercatat dalam sejarah. Penciptaan "maskot" daerah menjadi penting, tidak sekedar menjadi ikon ciri khas suatu daerah, namun lebih dari itu. Maskot akan memiliki nilai historis yang melekat- 